\title{
Uji Efektivitas Anthelmintik Formula Suspensi Biji Mentimun (Cucumissativus L.) Terhadap Cacing Gelang (Ascaris Lumbricoides)
}

\section{(The effectiveness Test of Cucumber Seeds Suspension Formula (Cucumissativus L.) Towards Roundworms (Ascaris Lumbricoides) as Anthelmintic)}

\author{
Nurfiddin Farid ${ }^{1}$, Andi Suparlan Isya Syamsu ${ }^{1}$, Ahmad Irsyad Aliah ${ }^{1}$, Anna Muthmainna \\ Murdi $^{1}$ \\ ${ }^{1 *}$ Fakultas Farmasi, Universitas Megarezky, Makassar, Indonesia. \\ E-mail: ojhy.kojhyro@gmail.com
}

Article Info:

Received: 11 November 2019 in revised form: 29 Januari 2020

Accepted: 26 Februari 2020

Available Online: 02 Maret 2020

Keywords:

Anthelmintic

Ascaris lumricoides

Nurfiddin Farid

Fakultas Farmasi

Universitas Megarezky

Makassar

90234

Indonesia

email: ojhy.kojhyro@gmail.com
Cucumber seeds suspension

Corresponding Author:

\begin{abstract}
Prevalenceworld Infection of worm infect more than 2 human being billion, at child very high range from $60-90 \%$. Is although made available by a more specific new drugs with the job more effective, worm eradication still represent one of problem which is because of social condition economics of some part world. Sum up the human being lighted upon also progressively increase the effect of migration, traffic and energy of air tourism, It has been conducted research to know cucumber seeds powder (Cucumis sativus L) can be made into form of suspension stock and to know stock of cucumber seeds suspension (Cucumis sativus L) can give effect of anthelmintic toward roundwoms Ascaris lumbricoides. The research was conducted by using experimental method. Powder of cucumber seeds (Cucumis sativus L) were made into suspension stock with 3 concentratios such as 5\%,10\%, 15\% concetrations and suspension without powder of cucumber seeds (Cucumis sativus L) with different addition subtance concentration. Testanimal used was roundworm (Ascaris lumbricoides) that was taken by pig's intestine. Treatment group consisted into five categories such as $125 \mathrm{mg}$ positive control of pamoat pirantel (Combantrin ${ }^{\circledR}$ ), negative control of suspension without powder of cucumber seeds (Cucumis sativus L), and category of cucumber seeds suspension (Cucumis sativus L) as 5\%, 10\%, and 15\%. Each group was soaked with $40 \mathrm{ml}$ test ingredient into petri dish. Then it was observed and writte the number of died worms in every minute. $100 \%$ observation of died worm was group of positive control at 405 minutes, negative control at 1710 minutes, 5\% concetration of cucumber seeds suspension stock at 540 minutes, 10\%concentration at 465 minutes and $15 \%$ concentration at 420 minutes. The result of research showed that cucumber seeds (Cucumis sativus L) can be made into suspension stock and effective as anhelmintic toward roundworms Ascaris lumbricoides.
\end{abstract}

Copyright (C) 2019 JFG-UNTAD This open access article is distributed under a Creative Commons Attribution (CC-BY-NC-SA) 4.0 International license.

How to cite (APA $6^{\text {th }}$ Style):

Farid, N., Syamsu, A. S. I., Aliah, A. I., Murdi, A. M. (2020). Uji Efektivitas Anthelmintik Formula Suspensi Biji Mentimun (Cucumissativus L.) Terhadap Cacing Gelang (Ascaris Lumbricoides). Jurnal Farmasi Galenika: Galenika Journal of Pharmacy (e-Journal), 6(1), 104-113. doi:10.22487/j24428744.2020.v6.i1.14307 


\section{ABSTRAK}

Prevalensi infeksi cacing didunia menjangkit lebih dari 2 miliar manusia, pada anak sangat tinggi berkisar antara $60 \%-90 \%$. Walaupun tersedia obat-obat baru yang lebih spesifik dengan kerja lebih efektif, pembasmian cacing masih tetap merupakan salah satu masalah yang disebabkan oleh kondisi sosial ekonomi dibeberapa bagian dunia. Jumlah manusia yang dihinggapinya juga semakin bertambah akibat migrasi, lalu lintas dan daya kepariwisataan udara,Telah dilakukan penelitian untuk mengetahui serbuk biji mentimun (Cucumis sativus L.) dapat dibuat dalam bentuk sediaan suspensi dan untuk mengetahui sediaan suspensi biji mentimun (Cucumis sativus L.) dapat memberikan efek anthelmintik terhadap cacing gelang Ascaris lumbricoides. Penelitian dilakukan dengan metode eksperimental. Serbuk biji mentimun (Cucumis sativus L.) dibuat dalam sediaan suspensi dengan 3 konsentrasi yaitu 5\%, 10\%,15\% dan suspensi tanpa serbuk biji mentimun (Cucumis sativus L.) dengan konsentrasi zat tambahan yang berbeda-beda. Hewan uji yang digunakan berupa cacing gelang Ascaris lumbricoides yang diambil dari usus babi. Kelompok perlakuan terbagi dalam lima yaitu kontrol positif pirantel pamoat $\left(\right.$ Combantrin $\left.^{\circledR}\right) 125 \mathrm{mg}$, kontrol negatif suspensi tanpa serbuk biji mentimun (Cucumis sativus L.), dan kelompok suspensi biji mentimun (Cucumis sativus L.) 5\%, 10\%, 15\%. Tiap kelompok direndam dengan $40 \mathrm{ml}$ bahan uji dalam cawan petri. Kemudian diamati dan dicatat jumlah cacing yang mati pada setiap menit. Adapun hasil yang kami peroleh dari penelitian ini adalah $100 \%$ kematian cacing yaitu kelompok kontrol positif pada menit ke 405, kontrol negatif pada menit ke 1710, sediaan suspensi biji mentimun konsentrasi 5\% pada menit ke 540, 10\% pada menit ke 465, dan $15 \%$ pada menit ke 420 .

Kata kunci: Anthelmintik, Ascaris lumbricoides, Suspensi Biji Mentimun.

\section{PENDAHULUAN}

Negara Indonesia merupakan salah satu negara yang sering terjangkiti oleh berbagai penyakit yang sampai sekarang masih menjadi permasalahan. Salah satunya adalah penyaki cacingan. Cacingan merupakan penyakit infeksi yang disebabkan oleh parasit berupa cacing. Cacing umumnya tidak menyebabkan penyakit berat sehingga sering kali diabaikan walaupun sesungguhnya memberikan gangguan kesehatan. Tetapi dalam keadaan infeksi berat atau keadaan yang luar biasa, kecacingan cenderung memberikan analisa keliru ke arah penyakit lain dan tidak jarang dapat berakibat fatal (Margono, 2008).

Prevalensi infeksi cacing didunia menjangkit lebih dari 2 miliar manusia, pada anak sangat tinggi berkisar antara 60\% - 90\%. Walaupun tersedia obat-obat baru yang lebih spesifik dengan kerja lebih efektif, pembasmian cacing masih tetap merupakan salah satu masalah yang disebabkan oleh kondisi sosial ekonomi dibeberapa bagian dunia. Jumlah manusia yang dihinggapinya juga semakin bertambah akibat migrasi, lalu lintas dan daya kepariwisataan udara (Tjay \& Rahardja, 2007).

Cacingan umumnya ditemukan di daerah tropis dan subtropis dan beriklim basah dimana hygiene dan sanitasinya buruk. Penyakit ini merupakan penyakit infeksi paling umum menyerang kelompok masyarakat ekonomi lemah dan ditemukan pada berbagai golongan usia (WHO, 2011).

Satu atau lebih cacing parasit usus yang terdiri dari golongan nematoda usus yang penularannya melalui tanah atau biasa disebut dengan cacing jenis STH yaitu Ascaris lumbricoides (Cacing gelang). Cacing ini ditemukan pada semua umur, tetap sering ditemukan pada anak umur 5 - 9 tahun. Gejala dan ciri anak cacingan yaitu wajah agak pucat, lesu dan kurang bergairah, kurus dan perut agak buncit, berat badan tidak meningkat meski nafsu makan tidak berkurang, pada bayi sering mengalami gangguan lambung, mules, diare, atau sulit buang air besar (seperti gejala penyait maag). Meskipun infeksi cacing tidak menyebabkan kematian secara langsung bahkan sangat kecil namun penderita memiliki resiko tinggi tetular berbagai penyakit karena kondisi tubuh yang lemah, maka sebaiknya segera diobati apabila melihat gejala awal yang timbul, khususnya pada anak-anak (Brown, 1982). Salah satu tanaman berkhasiat yang ada di sekitar kita yaitu mentimun (Cucumissativus L.) yang berkhasiat sebagai peluruh air seni (diuretika), tekanan darah tinggi(hipertensi), menghaluskan kulit, obat-obat cacing (anthelmintik) (Rianto, 2016). 
Mentimun (Cucumis sativus L.) merupakan tanaman semusim yang bersifat menjalar atau merambat dengan perantaraan alat pemegang yang berbentuk spiral (Cahyono, 2006). Tanaman mentimun berasal dari bagian India, yakni lereng gunung Himalaya, yang kemudian berkembang ke wilayah Mediterania. Di kawasan Asia khususnya Indonesia mentimun baru dikenal sekitar dua abad sebelum Masehi. Di Jawa dan Sumatera, mentimun banyak ditanam di dataran rendah (Samadi, 2002)

Penelitian mentimun sebagai anthelmintik yang telah dilakukan sebelumnya hanya sebatas pada pengujian dengan menggunakan ekstrak, sirup dan jus buah mentimun. Penelitian mengenai formulasi suspensi biji mentimun sebagai anthelmintik belum pernah dilakukan sebelumnya. Pada penelitian sebelumnya banyak menggunakan hewan coba Ascaridia galli dan penggunaan hewan coba Ascaris lumbricoides masih sangat kurang. Berdasarkan alasan di atas, penulis membuat penelitian Anthelmintik biji mentimun yang dibuat dalam formula suspensi yang diujikan pada hewan coba cacing gelang Ascarislumbricoides dengan menggunakan metode pengukuran waktu kematian cacing.

\section{METODE PENELITIAN}

\section{Jenis Penelitian}

Penelitian ini menggunakan metode eksperimental laboratorium pada bidang Teknologi Sediaan Farmasi dan Farmakologi untuk mengetahui efek anthelmintik sediaan suspensi biji Mentimun (Cucumis sativus L.)

\section{Waktu dan Tempat Penelitian}

Penelitian ini dimulai pada tanggal Mei - September 2019 di Laboratorium Teknologi Sediaan Farmasi dan Laboratorium Farmakologi, Universitas Megarezky di Kota Makassar, Sulawesi Selatan.

\section{Alat dan Bahan}

Alat-alat yang digunakan dalam penelitian ini antara lain alu, batang pengaduk, cawan petri, cawan porselin, gelas ukur (Pyrex), gelas piala (Pyrex), kaki tiga, lap halus, lap kasar, lumpang, sudip, pipet tetes, sendok tanduk, termometer (ASTM), dan timbangan elektrik (digital).

Bahan-bahan yang digunakan dalam penelitian ini adalah air suling, aluminium foil, cacing Ascaris lumbricoides, kertas perkamen, Lemon Oil, $\mathrm{NaCl}$ 0,9\%, Na.CMC, Natrium Benzoat, serbuk biji mentimun (Cucumis sativus L.), sirup simplex dan spritus.

\section{Pengambilan dan Penyiapan Sampel}

\section{Pengambilan Sampel}

Sampel mentimun (Cucumis sativus $\mathrm{L}$ ) yang digunakan adalah tanaman yang diperoleh dari kabupaten Enrekang, Sulawesi Selatan. Pengambilan sampel dilakukan pagi hari dengan mengambil mentimun yang sudah matang yang ditandai dengan warna hijau yang mulai memudar.

\section{Pengolahan Sampel}

Langkah pertama dalam pengolahan sampel yaitu melakukan sortasi basah. Sortasi basah dilakukan untuk memisahkan kotoran-kotoran atau bahan-bahan asing lainnya dari bahan baku. Sampel yang telah melalui tahap sortasi basah kemudian dicuci bersih dengan air mengalir lalu ditiriskan. Sampel yang telah dicuci kemudian dikeringkan dengan cara diangin - anginkan, setelah kering dipisahkan biji dari daging buah. Biji mentimun yang telah dipisahkan dari daging kembali dikeringkan dengan cara diangin-anginkan sampai kering. Biji mentimun yang telah kering diblender hingga terbentuk serbuk biji mentimun kemudian di ayak dengan ayakan mesh 60. 


\section{Pemilihan dan Penyiapan Hewan Uji}

Hewan uji yang digunakan adalah cacing gelang Ascaris lumbricoides yang diperoleh dari rumah potong ternak babi di Kab. Maros, Kec. Moncongloe. Pengambilan cacing gelang Ascaris lumbricoides ini adalah dengan cara usus babi dipotong membujur, cacing gelang Ascaris lumbricoides dalam usus ditampung kemudian dicuci dengan larutan $\mathrm{NaCl} 0,9 \%$ sampai bersih.

Cacing yang telah bersih ditampung dalam wadah yang berisi larutan $\mathrm{NaCl} 0,9 \%$ kemudian disimpan pada suhu ruangan sebelum digunakan. Cacing yang digunakan adalah cacing yang masih hidup dan menunjukkan gerak aktif, ukuran berbeda dan disimpan untuk digunakan tidak lebih dari 24 jam sejak diambil dari rumah pemotongan hewan.

\section{Formulasi Suspensi Biji Mentimun}

Tabel 3. Formula suspensi Biji Mentimun (Cucumis sativus L.)

\begin{tabular}{lcccccc}
\hline No & Nama Bahan & Kegunaan & \multicolumn{4}{c}{ Konsentrasi (\%) } \\
\hline & & & - & 5 & 10 & 15 \\
\cline { 3 - 6 } 1 & Serbuk biji mentimun & Zat Aktif & 0,4 & 0,3 & 0,2 & 0,1 \\
2 & Na CMC & Pensuspensi & 0.1 & 0,1 & 0,1 & 0,1 \\
3 & Natrium Benzoat & Pengawet & 15 & 20 & 25 & 30 \\
4 & Sirup Simplex & Pemanis & 3 & 5 & 7 & 10 \\
5 & Lemon Oil & Pengaroma & 2 & 4 & 5 & 6 \\
6 & Tartrazin & Pewarna & tetes & tetes & tetes & tetes \\
7 & Air Suling & Pembawa & & Ad 100 ml & \\
\hline
\end{tabular}

Proses pembuatan suspensi diawali dengan mengkalibrasi botol $100 \mathrm{ml}$ yang akan digunakan sebagai wadah penyimpanan suspensi. Dibuat koloidal Na CMC dengan cara dilarutkan Na CMC ke dalam lumpang dengan menggunakan air panas $\left(80^{\circ} \mathrm{C}\right)$ sambil diaduk perlahan sampai terbentuk larutan koloidal Na CMC. Ditambahan serbuk bji mentimun (Cucumis sativus L.), Sirup Simplex, Natrum Benzoat, dan lemon oil ke dalam koloidal Na CMC, lalu dihomogenkan. 


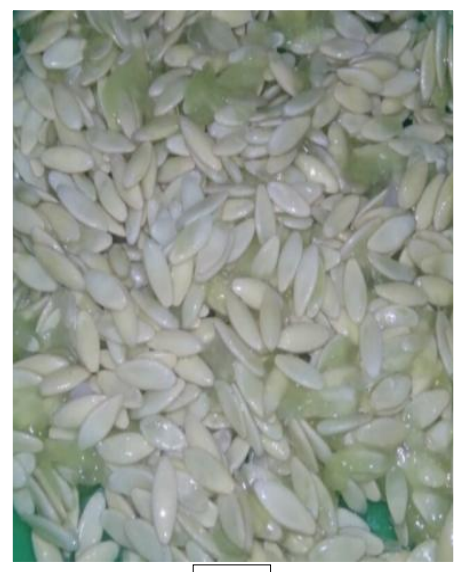

A

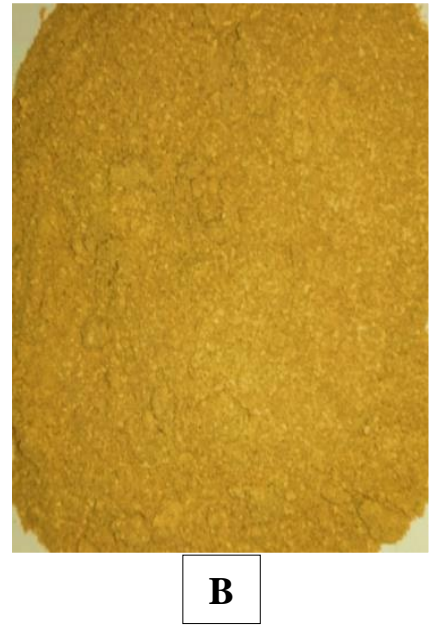

Gambar 1. Biji mentimun (A) Sebelum diolah, (B) Setelah diolah/diserbukkan

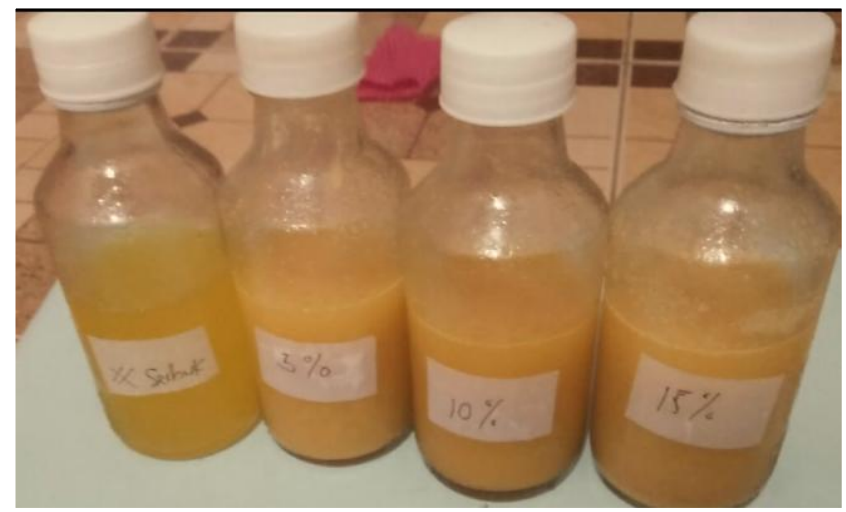

Gambar 2. Sediaan suspensi biji mentimun

\section{Pelaksanaan Uji Efek Anthelmintik Secara In Vitro}

Hewan uji masing-masing dikelompokkan menjadi 5 kelompok, hewan dalam 1 kelompok ditempatkan bersama dalam cawan petri. Pada kelompok 1 sampai kelompok 3 sebagai kontrol positif dan kelompok 4 sebagai kontrol negatif sedangkan kelompok 5 sampai kelompok 6 direndam dengan suspensi bij mentimun (Cucumis sativus.L.), dan diamati dan dicatat waktu kematian cacing. Pengamatan terhadap kematian cacing dilakukan dengan cara menyentuh cacing dengan batang pengaduk. Jika diam, cacing tersebut dipindahkan ke dalam air dengan suhu $50^{\circ} \mathrm{C}$ dan diamati kembali gerakannya. Setiap cacing yang masih memperlihatkan gerakan pada kedua arah dicatat sebagai masih hidup, sedangkan yang tidak bergerak atau memperlihatkan hanya gerakan kecil pada ujungnya dianggap sudah mati.

Kelompok 1: Direndam dengan Suspensi Pirantel pamoat $125 \mathrm{mg}$ sebagai kontol positif

Kelompok 2: Direndam dengan suspensi tanpa biji mentimunsebagai kontrol negatif

Kelompok 3: Direndam dengan suspensi biji mentimun 0,5\% b/v

Kelompok 4: Direndam dengan suspensi bii mentimun $10 \% \mathrm{~b} / \mathrm{v}$

Kelompok 5: Direndam dengan suspensi biji mentimn $15 \% \mathrm{~b} / \mathrm{v}$

\section{Pengumpulan Data}

Data dari keefektifan formulasi akan diolah dalam bentuk tabel dan grafik terhadap waktu. 


\section{HASIL DAN PEMBAHASAN}

\section{Hasil Pengujian}

Data hasil pengujian efek suspensi biji mentimun (Cucumis sativus L.) terhadap cacing Ascaris lumbricoides secara in-vitro yaitu sebagai berikut:

Tabel 4. Persentase jumlah cacing yang mati

\begin{tabular}{|c|c|c|c|c|c|}
\hline \multicolumn{5}{|c|}{ Persentase Efektivitas Formulasi } & \multirow{2}{*}{$\begin{array}{c}\text { Waktu } \\
\text { Menit }\end{array}$} \\
\hline \multicolumn{2}{|c|}{ Kelompok Kontrol } & \multicolumn{3}{|c|}{ Suspensi Biji Mentimun } & \\
\hline $\begin{array}{c}\text { Pirantel } \\
\text { Pamoat } 125 \\
\text { mg }\end{array}$ & $\begin{array}{c}\text { Suspensi } \\
\text { Tanpa Serbuk }\end{array}$ & $5 \%$ & $10 \%$ & $15 \%$ & Menit \\
\hline 0 & 0 & 0 & 0 & 0 & 15 \\
\hline 0 & 0 & 0 & 0 & 0 & 60 \\
\hline 0 & 0 & 0 & 0 & 0 & 120 \\
\hline 0 & 0 & 0 & 0 & 0 & 180 \\
\hline 0 & 0 & 0 & 0 & 0 & 240 \\
\hline 0 & 0 & 0 & 0 & 0 & 300 \\
\hline 1 & 0 & 0 & 0 & 1 & 360 \\
\hline \multirow[t]{10}{*}{1} & 0 & 0 & 0 & 0 & 390 \\
\hline & 0 & 0 & 0 & 1 & 420 \\
\hline & 0 & 0 & 1 & & 435 \\
\hline & 0 & 0 & 1 & & 465 \\
\hline & 0 & 0 & & & 480 \\
\hline & 0 & 1 & & & 495 \\
\hline & 0 & 1 & & & 540 \\
\hline & 0 & & & & 600 \\
\hline & 0 & & & & 1695 \\
\hline & 2 & & & & 1710 \\
\hline
\end{tabular}

\section{Keterangan :}

0 : Tidak ada cacing yang mati

1 : Kematian 1 ekor cacing gelang Ascaris lumbricoides

2 : Kematian 2 ekor cacing gelang Ascaris lumbricoides 


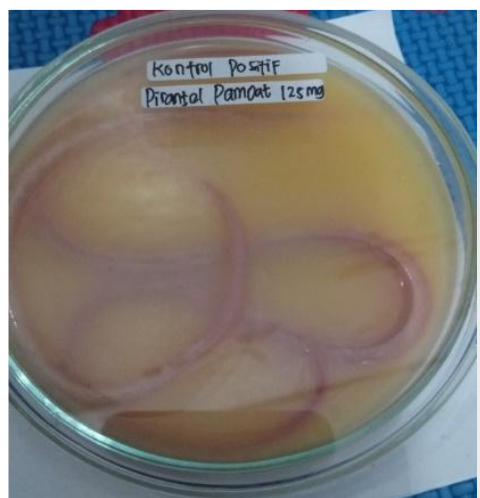

A

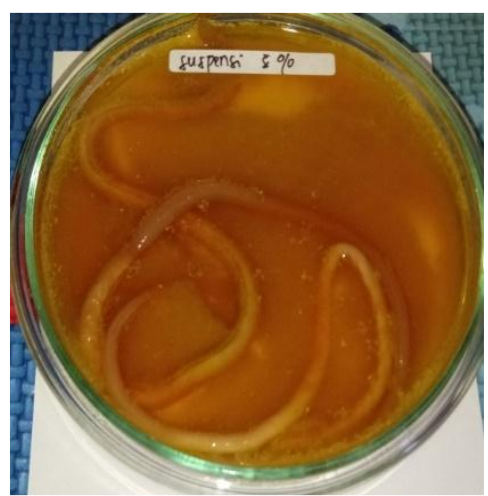

C

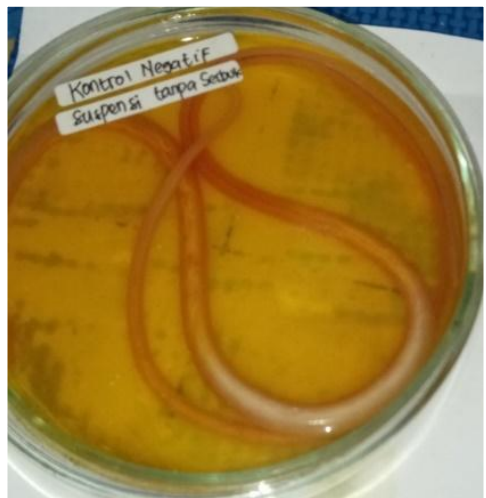

B

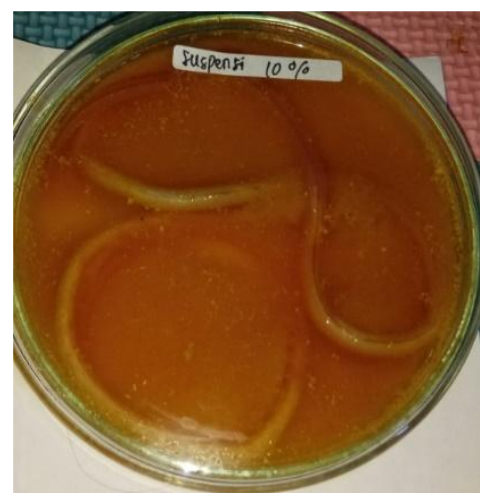

D

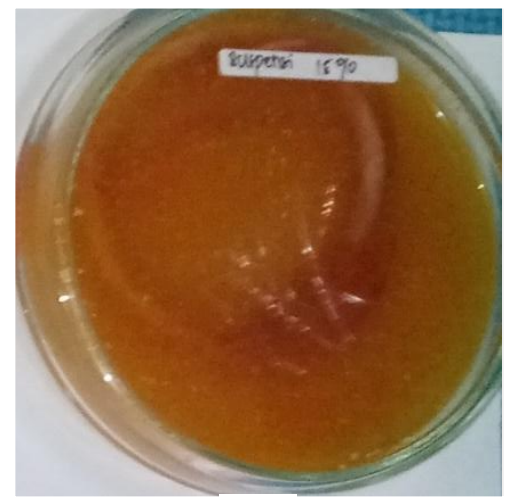

$\mathbf{E}$

Gambar 3. Sediaan suspensi biji mentimun (A) Kontrol positif, (B) Kontrol negatif, (C) 5\%, (D) 10\%, (E) $15 \%$.

\section{Pembahasan}

Pada penelitian ini digunakan biji mentimun karena telah dilakukan penelitian sebelumnya yang membuktikan bahwa biji mentimun dapat berkhasiat sebagai anthelmintik. Menurut Rianto et al., (2016), tentang "Uji Efektivitas Daya Anthelmintik Ekstrak Biji Mentimun (Cucumis sativus,L.) terhadap Cacing Ascaridia galli Secara In Vitro" bahwa ekstrak biji mentimun (Cucumis sativum L.) dapat berkhasiat sebagai anthelmentik, dan pada penelitian lanjutan tentang "Uji Efektiitas Daya Anthelmintik Jus Biji Mentimun (Cucumis sativus, L.) terhadap Cacing Ascaridia galli Secara In Vitro" bahwa jus biji mentimun berkhasiat sebagai anthelmintik. 
Buah mentimun yang digunakan diambil dari Kabupaten Enrekang, Sulawesi Selatan. Pengambilan sampel dilakukan pada pagi hari dengan mengambil mentimun yang telah matang ditandai dengan warna hijau dari kulit yang mulai memudar diganti dengan warna putih. Setelah dipetik dilakukan pengolahan yaitu dipisahkan biji dari daging buah kemudian dilakukan sortasi basah, pencucian dengan air mengalir, pengeringan dengan cara diangin-anginkan hingga kering kemudian di blender dan diayak menggunakan ayakan mesh 60 hingga diperoleh serbuk biji mentimun.

Serbuk biji mentimun yang telah diperoleh dibuat dalam sediaan suspensi menggunakan 4 macam formula yaitu pada formula I (tanpa serbuk buji mentimun) terdiri Na CMC 0,4\%, Natrium Benzoat $0,1 \%$, sirup simplex 15\%, Lemon oil 3\%, Tartrazin 2\%, air suling ad $100 \mathrm{ml}$; Formula II yaitu Serbuk biji mentimun 5\%, Natrium Benzoat 0,1\%, Sirup Simplex 20\%, Lemon oil $5 \%$, Tartrazin 5 tetes dan air suling ad $100 \mathrm{ml}$; Formula III yaitu serbuk biji mentimun 10\%, Natrium Benzoat 0,1 \%, Sirup Simplex 25\%, Lemon oil $7 \%$, Tartrazin 7 tetes dan air suling ad $100 \mathrm{ml}$, dan Formula IV yaitu Serbuk biji mentimun 15\%, Natrium Benzoat 0,1\%, Sirup Simplex 30\%, Lemon oil 10\%, Tartrazin 6\% dan air suling ad $100 \mathrm{ml}$. Tiap-tiap formula tersebut ditimbang dan disiapkan alat yang digunakan. Kemudian dipanaskan air pada suhu $80^{\circ} \mathrm{C}$ kemudian dibuat koloidal Na CMC, dan setelah terbentu koloidal maka serbuk biji mentimun dituang ke dalam koloidal Na CMC dan dihomogenkan. Setelah homogen maka timbahkan Natrium benzoat, Sirup simplex, Lemon oil, Tartrazin sesuai konsentrasi kemudian dicukupkan sampai $100 \mathrm{ml}$ air suling.

Penelitian ini dilakukan secara in vitro yakni suatu proses yang dilakukan untuk menunjukkan gejala yang diteliti diluar tubuh makhluk hidup dalam kondisi laboratorium.Untuk hewan uji yang digunakan adalah cacing gelang Ascaris lumbricoides var Suum, ini merupakan golongan nematoda (cacing dalam usus) yaitu cacing yang paling banyak menjangkiti manusia. Cacing ini terdapat di usus babi.

Cacing Ascaris lumbricoides diambil dari usus babi dan dimasukkan ke dalam larutan $\mathrm{NaCl} 0,9 \%$ sebagai mediumnya karena sifatnya yang isotonis, yang bertujuan untuk menjaga agar pada pengambilan hingga sebelum digunakan cacing tetap nyaman dan membran sel tubuh cacing tidak rusak akibat perubahan kondisi.

Pada pengujian terhadap cacing Ascaris lumbricoides dibagi dalam 5 kelompok perlakuan yaitu tiap kelompok terdiri dari 2 ekor cacing dayng direndam dengan 4 macam sediaan suspensi ,kontrol positif dan kontrol negatif. Kelompok 1 suspensi pirantel pamoat (Combantrin ${ }^{\circledR}$ ) 0,125\% sebagai kontrol positif, kelompok 2 suspensi tanpa serbuk biji mentimun sebagai kontrol negatif, kelompok 3 dengan suspensi biji mentimun 5\%, kelompok 4 dengan suspensi biji mentimun $10 \%$ dan kelompok 5 dengan suspensi biji mentimun 15\%. Pengamatan kematian cacing dimulai pada pukul 14.45 WITA dan diamati setiap jam ke $0,2,4,6,8,10$. Jika terdapat cacing yang diam maka cacing dipindahkan ke dalam air yang bersuhu $50^{\circ} \mathrm{C}$ untuk menstimulasi otot cacing untuk bergerak, kemudian dicatat waktu dan jumlah cacing yang mati.

Obat yang digunakan untuk mengobati penyakit cacingan akibat cacing gelang Ascaris lumbricoides adalah pirantel pamoat yang merupakan obat pilihan pertama olehmasyarakat karena pirantel pamoat efektif dan memiliki efek samping yang ringan. Mekanisme kerja Pirantel pamoat dengan melumpuhkan cacing dewasa dan cacing yang belum dewasa dengan memblokade neuromuskular (Mustchler, 1991), serta menimbulkan depolarisasi pada otak cacing dan meningkatkan frekuensi impuls sehingga cacing mati dalam keadaan kolinesterasi (Ganiswara, 1995). Sedangkan mekanisme kerja dari ekstrak biji pepaya yaitu dengan mengkoagulasi albumin yang merupakan lapisan kulit dari cacing gelang mencerna protein dalam tubuh cacing sehingga tubuh cacing menjadi lemas dan mati.

Hasil penelitian menunjukkan bahwa Suspensi pirantel pamoat (Combantrin ${ }^{\circledR}$ ) $125 \mathrm{mg}$ sebagai kontrol positif memperlihatkan efek kematian cacing $100 \%$ pada menit ke 405 , sediaan supensi biji mentimun 5\% menunjukkan kematian cacing pada menit ke 390 , sediaan suspensi biji mentimun 10\% 
menunjukkan kematian cacing pada menit ke 465 dan suspensi biji mentimun $15 \%$ menunjukkan kematian cacing pada menit ke 420.

Pada penelitian Rinaldy, (2013), "Uji Efek Antiaskariasis Ekstrak Etanol Biji Pepaya (Carica papaya L.) Terhadap Cacing Gelang (Ascaris lumbricoides) Secara In Vitro" menunjukkan bahwa Ekstrak biji pepaya (Carica papaya L.) memperlihatkan efek kematian cacing $100 \%$ pada jam ke 1 dengan konsentrasi kontrol positif pirantel pamoat $0,025 \% \mathrm{~b} / \mathrm{v}$ dan konsentrasi ekstrak $16 \% \mathrm{~b} / \mathrm{v}$, pada jam ke 4 dengan konsentrasi $4 \% \mathrm{~b} / \mathrm{v}$, pada jam ke 6 dengan konsentrasi $2 \% \mathrm{~b} / \mathrm{v}$, dan pada jam ke 12 dengan konsentrasi $1 \% \mathrm{~b} / \mathrm{v}$ dan $0,5 \% \mathrm{~b} / \mathrm{v}$, sedangkan pada jam ke 25 memperlihatkan efek kematian cacing sebesar $100 \%$ pada kontrol negatif Na CMC 0,2 \%. Perbedaan penelitian ini dengan penelitian saya terletak pada sampel, hewan uji yang sama dan hasil. Dimana pada penelitian ini menunjukkan efek kematian cacing yang lebih cepat dibandingkan pada penggunaan sediaan suspensi biji mentimun.

Kemudian pada penelitian Rianto et al., (2016), "Uji Efektivitas Daya Anthelmintik Ekstrak Biji Mentimun (Cucumis sativus,L.) terhadap Cacing Ascaridia galli Secara In Vitro" menunjukkan 100 \% kematian cacing, pada kontrol positif pirantel pamoat $0,2 \%$ pada jam ke 11, pirantel pamoat $0,4 \%$ pada jam ke 8 , pirantel pamoat $0,6 \%$ pada jam ke 7 , sedangkan pada ekstrak biji mentimun pada konsentrasi $15 \%$ menunjukkan kematian cacing pada jam ke 8 , konsentrasi $30 \%$ dan $60 \%$ pada jam ke 7, dan pada kontrol negatif larutan $\mathrm{NaCl} 0,9 \%$ menunjukkan kematian cacing pada jam ke 36 . Perbedaan penelitian ini dengan penelitian saya terletak pada sampel, dimana penelitian ini menggunakan jus biji mentimun, dan mengunakan konsentrasi 15\%, 30\% 60\%, hewan uji yakni cacing Ascaridia galli, dan suspensi pirantel pamoat $0,2 \%, 0,4 \% 0, \%$. Hasil dari penelitian inimenunjukkan bahwa efek kematian cacing oleh ekstrak biji mentimun lebih cepat dibandingkan sediaan suspensi biji mentimun, karena konsentrasi yang digunakan lebih tinggi yaitu 15\%, 30\%, 60\% sedangkan pada suspensi biji mentimun menggunakan konsentrasi 5\%,10\% dan 15\%. Berdasarkan hasil penelitian terdahulu maka dapat dikatakan bahwa semakin tinggi konsentrasi sampel maka efektivitas anthelmintik akan semakin baik yakni semakin tingginya angka kematian cacing.

Setelah dilakukannya pengamatan, maka data diolah dalam bentuk tabel dan grafik terhadap waktu yang menunjukkan keefektifan perlakuan dari kontrol positif, kontrol negatif dan sediaan suspensi biji mentimun

\section{KESIMPULAN}

Berdasarkan hasil penelitian dan pembahasan yang telah dilakukan, maka dapat disimpulkan bahwa Serbuk biji mentimun (Cucumis sativus L.) dapat dibuat dalam sediaan suspensi, Sediaan suspensi biji mentimun efektif sebagai anthelmintik pada cacing Ascaris lumbricoides

\section{UCAPAN TERIMAKASIH}

Ucapan terima kasih penulis ucapkan kepada pihak-pihak terkait yang membantu dalam penyelesaian penelitian ini, khususnya kepada Kementrian Riset, Teknologi dan Pendidikan Tinggi yang membiayai keseluruhan pelaksanaan penelitian ini dan kepada pihak-pihak Universitas Megarezky pada umumnya dan terkhusus kepada program studi S1 Farmasi Universitas Megarezky. 


\section{DAFTAR PUSTAKA}

Brown, H.W. (1982). Dasar Parasitologi Klinis, (Edisi ke-.3). Jakarta: PT Gramedia.

Cahyono, B. (2003). Teknik dan Strategi Budidaya Mentimun. Yogyakarta : Yayasan Pustaka Nusatama.

Ganiswara, S. G. (1995). Farmakologi Dan Terapi edisi IV. Jakarta: UI Press.

Margono, S. (2008). Nematoda Usus Buku ajar Parasitologi Kedokteran. Edisi 4. Jakarta: FK UI.

Mutschler, E. (1991). Dinamika Obat Edisi V. Bandung: Penerbit ITB.

Rianto, L., Astuti, I., \& Prihatiningrum, I. (2017). Uji Efektivitas Daya Anthelmintik Jus Biji Mentimun (Cucumis Sativum, L) Terhadap Cacing Ascaridia Galli Secara In Vitro. Jurnal Ilmiah Manuntung, 2(1), 1-7.

Rinaldy, A. (2013). Uji Efek Antiaskariasis Ekstrak Etanol Biji Pepaya (Carica papaya L.) Terhadap Cacing Gelang (Ascaris lumbricoides) Secara In Vitro (Undergraduate Thesis). Universitas Islam Negeri (UIN) Alauddin Makassar, Indonesia.

Samadi, B. (2002). Teknik Budidaya Mentimun Hibrida. Yogyakarta: Kanisius.

Tjay, T. H., \& Rahardja, K. (2007). Obat-Obat Penting. Edisi 6. Jakarta: PT Elex Media Komputindo.

WHO, (2011). Global Status Report On Non Communicable Diseases 2010. Diakses http://www.who.int/nmh/publications/ncd_report_chapter1.pdf 